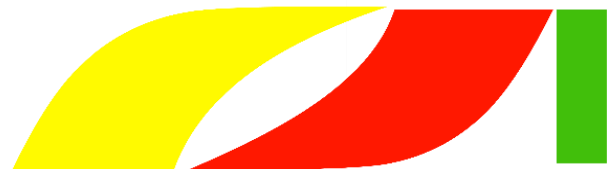

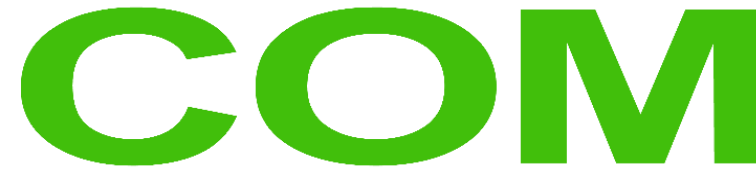 \\ Jurnal Informatika dan Teknologi Komputer
}

Vol. 02 No. 01 (2021) $57-61$

E-ISSN :2774-7115 P-ISSN: 2775-2089

\section{Sistem Pendukung Keputusan Penilaian Kinerja Guru Terbaik pada TK IT AN-NUR Menggunakan Metode Graphic Rating Scales}

\author{
Dhiva Andini Putri ${ }^{1}$, Sri Lestari ${ }^{2}$, Dadang Iskandar Mulyana ${ }^{3}$, Wahyu Saputro ${ }^{4}$ \\ ${ }^{1,2,3,4}$ Sistem Informasi, Sekolah Tinggi Ilmu Komputer Cipta Karya Informatika \\ ${ }^{1}$ putriandinidhiva@gmail.com, ${ }^{2}$ Sri.lestari1203@gmail.com*., ${ }^{3}$ mahvin2012@gmail.com, ${ }^{4}$ wahyudahsyat@gmail.com
}

\begin{abstract}
The development of technological sophistication today, is needed in various fields, especially in the field of education. Technology is needed in the field of education to make it easier for schools to obtain data, provide teaching and assess the development of schools, teachers, and students to be more efficient, fast and effective. Schools are where students receive guidance and instruction from educators or teachers. The quality of an educator is needed in realizing smart, skilled, and creative students. Therefore, they are required to have their own advantages that will make them the best teachers. Teacher performance is needed to improve the quality and quality of an educator. With a good community assessment of the TK IT An-Nur, teachers have a responsibility to always improve the quality and quality. Kindergarten teachers are required to be creative in guiding students, not only introduce children to lessons but also introduce children about manners and moral daily life. TK IT An-nur still uses a manual and has not been computerized in the assessment of teacher performance, so in determining the best teacher in each year is still groping. With the best teacher decision support system with graphic rating scales method, it can facilitate principals and operators in the performance assessment process and get accurate results.
\end{abstract}

Keywords : Decision Support System, Teacher, Graphic Rating Scales.

\begin{abstract}
Abstrak
Berkembangnya kecanggihan teknologi saat ini, sangat dibutuhkan dalam berbagai bidang, khususnya dalam bidang pendidikan. Teknologi dibutuhkan dalam bidang pendidikan untuk mempermudah sekolah - sekolah memperoleh data, memberikan pengajaran serta menilai perkembangan sekolah, pengajar, maupun murid menjadi lebih efisien, cepat dan efektif. Sekolah merupakan tempat para siswa mendapatkan bimbingan dan pengajaran dari para pendidik atau guru. Kualitas seorang pendidik sangat dibutuhkan dalam mewujudkan murid yang cerdas, terampil, dan kreatif. Oleh sebab itu, mereka dituntut untuk memiliki keunggulan masing-masing yang akan menjadikan mereka sebagai guru terbaik. Kinerja guru dibutuhkan untuk meningkatkan mutu dan kualitas seorang pendidik. Dengan penilaian masyarakat yang cukup baik terhadap TK IT An-Nur, maka guru memiliki tanggung jawab untuk selalu meningkatkan mutu serta kualitas. Guru TK di tuntut untuk kreatifitas dalam membimbing anak didik,tidak hanya mengenalkan anak pada pelajaran tetapi juga mengenalkan anak tentang perilaku sopan santun dan kehidupan sehari - hari yang berakhlak. TK IT An-nur masih menggunakan cara yang manual dan belum terkomputerisasi dalam penilaian kinerja guru, sehingga dalam penentuan guru terbaik disetiap tahunnya masih meraba-raba. Dengan adanya sistem pendukung keputusan guru terbaik dengan metode graphic rating scales ini dapat memudahkan kepala sekolah dan operator dalam proses penilaian kinerja dan mendapatkan hasil yang akurat.
\end{abstract}

Kata kunci : Sistem Pendukung Keputusan, Guru, Graphic Rating Scales.

\section{Pendahuluan}

Berkembangnya kecanggihan teknologi saat ini, sangat dibutuhkan dalam berbagai bidang, khususnya dalam bidang pendidikan. Teknologi dibutuhkan dalam bidang pendidikan untuk mempermudah sekolah sekolah memperoleh data, memberikan pengajaran serta menilai perkembangan sekolah, pengajar, maupun murid menjadi lebih efisien, cepat dan efektif. Sekolah merupakan tempat para siswa mendapatkan bimbingan dan pengajaran dari para pendidik atau guru. Kualitas seorang pendidik sangat dibutuhkan dalam mewujudkan murid yang cerdas, terampil, dan kreatif. Oleh sebab itu, mereka dituntut untuk memiliki keunggulan masing-masing yang akan menjadikan mereka sebagai guru terbaik. Kinerja guru dibutuhkan 
untuk meningkatkan mutu dan kualitas seorang instansi, dimana penilaian meliputi beberapa kriteria" pendidik.

TK IT An-Nur merupakan Taman Kanak-Kanak Penentuan skala yang digunakan untuk memberikan Islam Terpadu yang terletak di cipinang muara,Jakarta skor atau bobot pada setiap kriteria yaitu dengan skala Timur. TK IT tersebut mempunyai grade atau penilaian likert 5 poin yang berarti penilaian dari nilai terkecil yang bagus di lingkungan dalam membimbing dan sampai besar yaitu Sangat baik $($ Outstanding) $=5$, Baik memberikan pengajaran terhadap anak didik. Dengan $($ Excellent $)=4$, Cukup Baik $($ Preety Good $)=3$, Kurang penilaian masyarakat yang cukup baik terhadap TK IT (Deficient) $=2$, Sangat kurang (Very Less $)=1$.

tersebut, maka guru memiliki tanggung jawab untuk Berdasarkan nilai akhir yang diperolah melalui selalu meningkatkan mutu serta kualitas. Guru TK di perhitungan, maka skala nilai tersebut seperti dibawah tuntut untuk kreatifitas dalam membimbing anak ini :

didik,tidak hanya mengenalkan anak pada pelajaran tetapi juga mengenalkan anak tentang perilaku sopan santun dan kehidupan sehari - hari yang berakhlak. Penilaian kinerja guru pada TK IT An-nur masih menggunakan cara yang manual dan belum terkomputerisasi, sehingga dalam penentuan guru terbaik disetiap tahunnya masih belum pasti.

Sistem penilaian kinerja guru merupakan sistem yang dirancang untuk mengidentifikasi penilaian kemampuan dan kreatifitas guru dalam melaksanakan tugasnya. Penilaian kinerja guru dapat mempengaruhi jenjang karir guru tersebut. Hasil dari penilaian kinerja guru dapat digunakan untuk memutuskan siapa yang berhak menyandang predikat sebagai guru terbaik pada sekolah tersebut. Dengan adanya penilaian kinerja guru dapat meningkatkan semangat bagi para guru-guru untuk bersaing dalam meningkatkan mutu dan kualitas dalam pembelajaran.

Berdasarkan permasalahan yang diuraikan diatas, maka penulis bermaksud untuk melakukan penelitian pada TK IT An-Nur guna membantu mengatasi permasalahan tersebut dengan membuat sebuah Sistem Pendukung Keputusan Penilaian Kinerja Guru Terbaik pada TK IT An-Nur Menggunakan Metode Graphic Rating Scales.

"Sebuah sistem pendukung keputusan yang optimal memiliki beberapa aspek, antara lain : sistem pendukung keputusan yaitu sistem yang sudah terkomputerisasi yang dapat digunakan oleh pengguna. Dirancangnya sistem pendukung keputusan guna dapat membantu pembuat keputusan dalam menyelesaikan suatu masalah dalam berbagai level manajemen dan bukan untuk mengganti posisi manusia sebagai pembuat keputusan.[1]“

\section{Metode Penelitian}

a. Jika nilai akhir guru diantara $>=0$ sampai $<=2,00$ maka nilai guru tersebut adalah $\mathrm{D}$.

b. Jika nilai akhir guru diantara $>2,00$ sampai $>=3,00$ maka nilai guru tersebut adalah $\mathrm{C}$.

c. Jika nilai akhir guu diantara $>3,00$ sampai $<=4,00$ maka nilai guru tersebut adalah $\mathrm{B}$.

d. Jika nilai akhir guru diantara $>4,00$ sampai $<=5,00$ maka nilai guru tersebut adalah $\mathrm{A}$.

Tahapan - tahapan dalam menggunakan metode graphic rating scales ini yaitu :

a. Menentukan kriteria apa saja yang masuk dalam penilaian dan boto pada masing - masing kriteria.

b. Menentukan subkriteria.

c. Menentukan jenis skala penilaian.

Perhitungan pada metode graphic rating scales ada 3 tahapan, yaitu :

Sub Kriteria $=$ jumlah nilai skor / banyaknya subkriteria

Kriteria = nilai subkriteria / banyaknya kriteria

Nilai Akhir $=$ Skor Absen*0,6 + K*0,4

\section{Hasil dan Pembahasan}

\subsection{Teknik Pengumpulan Data}

Dalam mengumpulkan data dan informasi pada TK IT An-Nur, maka peneliti menggunakan sebuah data primer yaitu hasil wawancara,observasi, dan studi literatur yang dilakukan di TK IT An-Nur.

a. Observasi

Observasi dilakukan dengan mengamati secara langsung TK IT An-Nur Jakarta Timur tentang permasalahan pada proses penentuan keputusan pemilihan guru terbaik setiap tahunnya. Dari observasi secara langsung peneliti mengetahui bahwa pada pemilihan guru terbaik di TK IT An-Nur masih menggunakan cara yang manual yang tentu hasilnya belum akurat dan tepat.

Metode yang digunakan dalam penelitian ini yaitu b. Wawancara

metode graphic rating scales, "Metode graphic rating Wawancara dilakukan dengan bertanya langsung scales adalah metode penilaian yang menggunakan kepada kepala sekolah dan operator pada TK IT Anskala likert bobot $1-5$ dari terendah hingga tertinggi, Nur Jakarta Timur. Untuk mengetahui apa saja yang yaitu sangat kurang, kurang, cukup baik, baik, dan menjadi hambatan dan permasalahan pada proses sangat baik.

penentuan keputusan guru terbaik dan menanyakan

Dari definisi yang telah dijabarkan maka dapat kriteria apa saja yang memungkinkan untuk jadi diambil garis tengah bahwa metode GRS adalah penilaian setiap guru.

metode penilaian pekerja yang membandingkan nilai c. Studi literatur

kinerja setiap pekerja terhadap standar masing masing

Dari hasil tersebut peneliti dapat mengetahui masalah penilaian kinerja guru yang sedang berjalan

Jurnal J-ICOM (Jurnal Informatika dan Teknologi Komputer) Vol. 02 No. 01 (2021) 57 - 61 
dan apa yang dibutuhkan TK IT An-Nur dalam penilaian kinerja guru pada sistem yang baru.

\subsection{Analisa Sistem Berjalan}

Pada gambar dibawah ini merupakan gambar diagram alur (flowmap) yang sedang berjalan pada sistem penilaian guru terbaik di TK IT An-Nur Jakarta Timur.

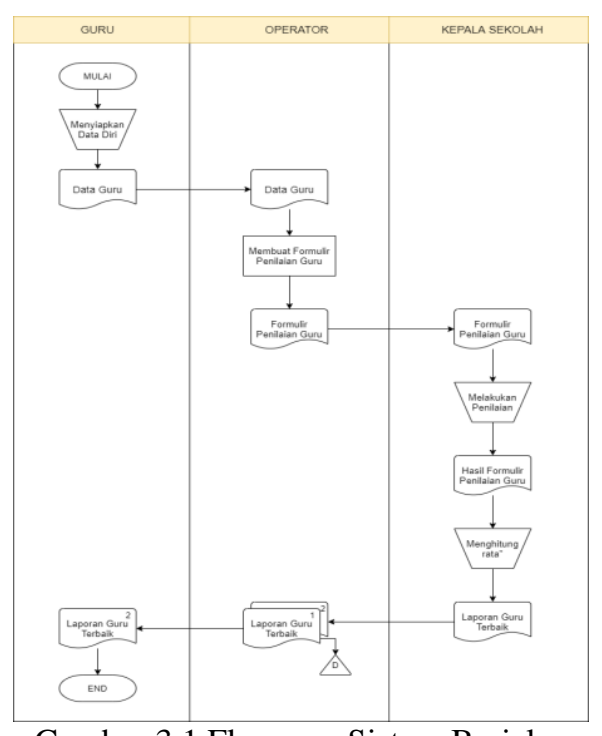

Gambar 3.1 Flowmap Sistem Berjalan

\subsection{Data Penelitian}

Sistem pendukung keputusan penilaian kinerja guru terbaik dengan metode graphic rating scales, membutuhkan sebuah data kualitatif yang berupa kriteria-kriteria yang dibutuhkan dalam penilaian kinerja guru terbaik pada TK IT An-Nur. Kriteria yang didapat untuk penilaian kinerja guru terbaik pada TK IT An-Nur tersebut, antara lain :

Tabel 3.1 Data Kriteria Penelitian

\begin{tabular}{|c|c|c|}
\hline KRITERIA & & SUBKRITERIA \\
\hline $\begin{array}{l}\text { 1. Penilaian } \\
\text { Profesional ( } \\
\text { Penialaian } \\
\text { kemampuan para } \\
\text { guru dalam } \\
\text { mengerjakan } \\
\text { tugas-tugas nya) }\end{array}$ & a. & $\begin{array}{l}\text { Menguasai materi } \\
\text { pembelajaran } \\
\text { terutama } \\
\text { pengetahuan dalam } \\
\text { agama. } \\
\text { Menguasai standar } \\
\text { kompetensi (SK) } \\
\text { pelajaran, } \\
\text { kompetensi dasar } \\
\text { (KD) pelajaran, dan } \\
\text { tujuan pembelajaran. } \\
\text { Pengembangan } \\
\text { materi dengan } \\
\text { kreatifitas. } \\
\text { Mampu menguasai } \\
\text { teknologi informasi } \\
\text { dan komunikasi } \\
\text { dalam proses belajar }\end{array}$ \\
\hline
\end{tabular}

\begin{tabular}{|c|c|c|}
\hline & & mengajar. \\
\hline & $\begin{array}{l}\text { Penilaian } \\
\text { Pedagogik } \\
\text { (Kemampuan dan } \\
\text { ketrampilan guru } \\
\text { untuk bisa } \\
\text { mengelola suatu } \\
\text { proses } \\
\text { pembelajaran dan } \\
\text { interaksi belajar } \\
\text { mengajar dengan } \\
\text { peserta didik) }\end{array}$ & 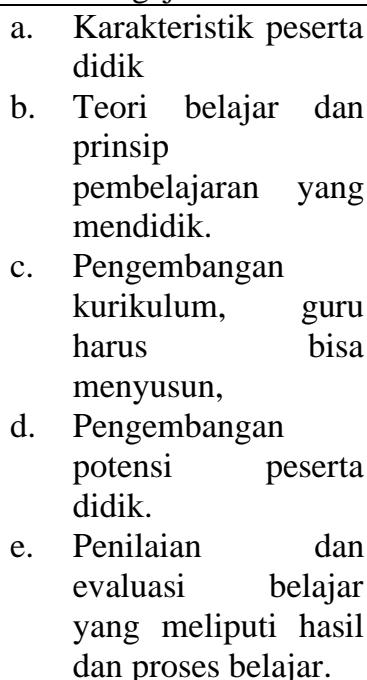 \\
\hline & $\begin{array}{l}\text { Penilaian } \\
\text { Kepribadian ( } \\
\text { Penilaian terhadap } \\
\text { sikap yang } \\
\text { dimiliki oleh guru) }\end{array}$ & $\begin{array}{llr}\text { a. } & \text { Sikap kejujuran } \\
\text { b. } & \text { Sopan santun } & \\
\text { c. } & \text { Rasa empati } & \\
\text { d. } & \text { Kesabaran } & \\
\text { e. } & \text { Sikap } & \text { disiplin } \\
& \text { terhadap } & \text { aturan } \\
& \text { sekolah. } & \end{array}$ \\
\hline & $\begin{array}{l}\text { Penilaian Sosial ( } \\
\text { Penilaian terhadap } \\
\text { sikap komunikasi } \\
\text { guru pada } \\
\text { lingkungan } \\
\text { sekolah) }\end{array}$ & $\begin{array}{ll}\text { a. } & \text { Sikap dan } \\
& \text { komunikasi terhadap } \\
\text { murid } & \text { dan } \\
\text { b. } & \text { Sikap } \\
\text { komunikasi terhadap } & \text { tenaga kependidikan } \\
\text { c. Sikap dan } & \text { komunikasi terhadap } \\
& \text { orang tua/ wali }\end{array}$ \\
\hline
\end{tabular}

\subsection{Implementasi Metode}

Dalam mengimplementasi metode graphic rating scales langkah pertamanya yaitu menentukan kriteria kriteria yang termasuk dalam penilaian kinerja guru pada TK IT An-Nur dan bobotnya. Pada TK IT An-Nur terdapat 4 aspek penilaian dan bobot untuk setiap kriteria dalam penilaian kinerja guru terbaik pada TK IT An-Nur yaitu ada 4 aspek atau penilaian :

Tabel 3.2 Nilai Bobot Kriteria

\begin{tabular}{|l|l|c|}
\hline No & \multicolumn{1}{|c|}{ Nama Kriteria } & $\begin{array}{c}\text { Persentasi } \\
\text { bobot }(\boldsymbol{\%})\end{array}$ \\
\hline 1. & Penilaian Profesional & $25 \%$ \\
\hline 2. & Penilaian Pedagogik & $25 \%$ \\
\hline 3. & Penilaian Kepribadian & $20 \%$ \\
\hline 4. & Penilaian Jumlah Absensi & $15 \%$ \\
\hline 5. & Penilaian Sosial & $15 \%$ \\
\hline
\end{tabular}

Setelah kriteria, sub kriteria, bobot dan rating nilai sudah ditentukan, proses selanjutnya yaitu menghitung 
hasil penilaian dari masing - masing kriteria dengan Dari hasil penilaian diatas, dapat disimpulkan bahwa bu cara :

Liza Zakiah yang berhak mendapat gelar guru terbaik

a. Perhitungan Hasil Sub Kriteria dengan perolehan nilai akhir tertinggi yaitu $\mathbf{4 , 7 2}$.

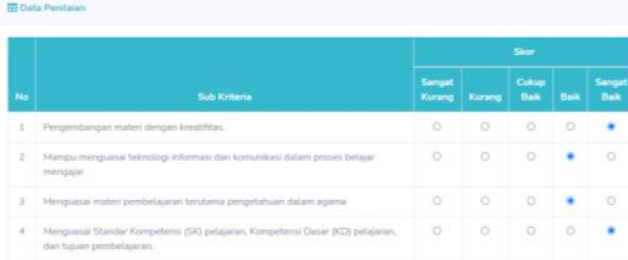

Gambar 3.2 Data Penilaian Profesional

Dengan skor penilaian mengukur respon subyek ke dalam 5 poin yaitu SANGAT BAIK $=5$, BAIK $=4$, CUKUP BAIK $=3$, KURANG $=2$, dan SANGAT KURANG $=1$, dapat dihitung sebagai berikut :

Sub Kriteria = jumlah nilai skor/banyaknya subkriteria $=(5+4+4+5) / 4$

$=\mathbf{4 , 5 0}$

b. Perhitungan Skor Kriteria

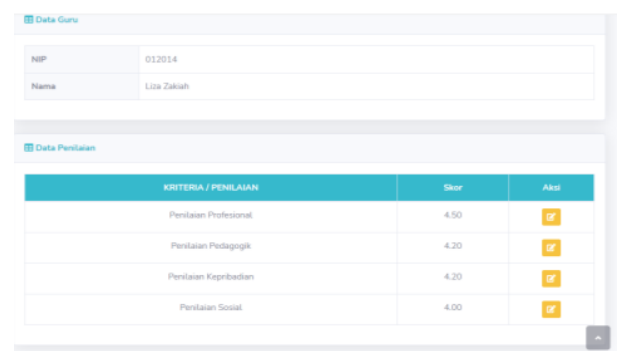

Gambar 3.3 Data Hasil Penilaian Kriteria

Kriteria $=$ nilai subkriteria $/$ banyaknya kriteria

$$
=(4,50+4,20+4,20+4,00) / 4
$$$$
=4,22
$$

\section{c. Perhitungan Hasil Akhir}

Hasil penilaian dari masing - masing kriteria di setiap guru di tambah dengan jumlah absen selama 3 bulan, dan karna jika dijumlah skor absen maka total melebihi dari skor tertinggi di metode graphic rating scales, maka rumus total menjadi, (Skor Absen*0,6) + (Skor Kriteria*0.4) sebagai berikut :

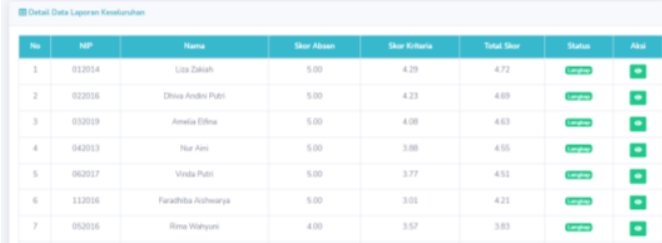

Gambar 3.4 Data Hasil Pemilihan Guru Terbaik

\subsection{Rancangan Pengujian Aplikasi}

Dalam penelitian sistem pendukung keputusan penilaian guru terbaik dengan metode graphic rating scales ini, penulis menjelaskan bagaimana proses rancangan pengujian pada sistem yang akan berjalan. Untuk itu diperlukannya pengujian sistem yang disebut pengujian user interface (UI). Pengujian ini bertujuan untuk mengetahui fungsi dari elemen- elemen atau menu-menu yang terdapat pada sistem pendukung keputusan penilaian guru terbaik ini apakah bekerja dengan baik atau tidak. Adapun rincian pengujian user interface (UI) dapat dilihat pada tabel dibawah ini :

\begin{tabular}{|c|c|c|}
\hline No & Keterangan & Ket \\
\hline 1. & $\begin{array}{l}\text { Login adalah menu untuk masuk } \\
\text { kedalam aplikasi dengan } \\
\text { memasukan username dan } \\
\text { password. }\end{array}$ & Berjalan \\
\hline 2. & $\begin{array}{l}\text { Dashboard adalah tampilan menu } \\
\text { utama pada aplikasi }\end{array}$ & Berjalan \\
\hline 3. & $\begin{array}{l}\text { Data Guru adalah menu untuk } \\
\text { operator menginput data diri } \\
\text { setiap guru. }\end{array}$ & Berjalan \\
\hline 4. & $\begin{array}{l}\text { Data periode adalah menu untuk } \\
\text { operator menginput periode tahun } \\
\text { ajaran dan semester untuk } \\
\text { penilaian dan batas waktu } \\
\text { penilaian. }\end{array}$ & Berjalan \\
\hline 5. & $\begin{array}{l}\text { Data kriteria adalah menu untuk } \\
\text { operator menginput jenis-jenis } \\
\text { kriteria yang menjadi patokan } \\
\text { dalam penilaian kinerja guru } \\
\text { terbaik. }\end{array}$ & Berjalan \\
\hline 6. & $\begin{array}{l}\text { Data sub-kriteria adalah menu } \\
\text { untuk operator menginput } \\
\text { deskripsi atau jenis jenis yang } \\
\text { terdapat di setiap kriteria. }\end{array}$ & Berjalan \\
\hline 7. & $\begin{array}{l}\text { Data pengguna adalah menu } \\
\text { untuk menambah kan atau }\end{array}$ & Berjalan \\
\hline
\end{tabular}




\begin{tabular}{|c|c|c|}
\hline & $\begin{array}{l}\text { mengurangi aktor yang dapat } \\
\text { mengakses sistem pendukung } \\
\text { keputusan penilaian guru terbaik } \\
\text { di TK ANNUR. }\end{array}$ & \\
\hline 8. & $\begin{array}{l}\text { Data penilaian adalah menu } \\
\text { untuk kepala sekolah } \\
\text { memberikan penilaian pada } \\
\text { setiap guru sesuai periode dan } \\
\text { kriteria kriteria yang terdapat di } \\
\text { penilaian. }\end{array}$ & Berjalan \\
\hline 9. & $\begin{array}{l}\text { Laporan keseluruhan adalah } \\
\text { menu untuk kepala sekolah } \\
\text { mengetahui siapa yang berhak } \\
\text { menjadi guru terbaik sesuai hasil } \\
\text { dari penilaian. }\end{array}$ & Berjalan \\
\hline 10. & $\begin{array}{l}\text { Laporan per-guru adalah menu } \\
\text { untuk mengetahui nilai masing- } \\
\text { masing guru }\end{array}$ & Berjalan \\
\hline 11. & $\begin{array}{l}\text { Cetak laporan keseluruhan adalah } \\
\text { menu untuk mencetak laporan } \\
\text { hasil dari penilaian dan hasil dari } \\
\text { penentuan guru terbaik sesuai } \\
\text { tahun pelajaran yang dipilih. }\end{array}$ & Berjalan \\
\hline 12. & $\begin{array}{l}\text { Cetak laporan per-guru adalah } \\
\text { menu untuk mencetak laporan } \\
\text { hasil dari penilaian pada masing- } \\
\text { masing guru. }\end{array}$ & Berjalan \\
\hline 13. & $\begin{array}{l}\text { Logout adalah menu untuk } \\
\text { keluar/ mengakhiri aktifitas di }\end{array}$ & Berjalan \\
\hline
\end{tabular}

\begin{tabular}{|l|l|l|}
\hline sistem pendukung keputusan & \\
penilaian guru terbaik. & & \\
\hline
\end{tabular}

\section{Kesimpulan}

Berdasarkan hasil penelitian yang telah dilakukan, mengenai Sistem Pendukung Keputusan Penilaian Kinerja Guru Terbaik pada TK IT An-Nur Menggunakan Metode Graphic Rating Scales dapat disimpulkan bahwa, proses penilaian kinerja guru pada TK IT An-Nur masih menggunakan cara yang manual dan dengan kriteria yang masih berganti-ganti dan belum memenuhi persyaratan, maka pada sistem pendukung keputusan penilaian kinerja guru terbaik ditentukan kriteria yang berdasarkan dengan Undang Undang No.14 tahun 2005. Pada sistem pendukung keputusan penilaian kinerja guru terbaik ini diterapkan metode graphic rating scales yang dapat mempermudah kepala sekolah dalam melakukan penilaian dan mendapatkan hasil yang akurat, dengan skala likert 5 poin yang berarti penilaian dari nilai terkecil sampai besar yaitu Sangat baik (Outstanding)= 5, Baik $($ Excellent $)=4$, Cukup Baik $($ Pretty Good $)=3$, Kurang $($ Deficient $)=2$, Sangat kurang $($ Very Less $)=1$.

\section{Ucapan Terimakasih}

Saya ucapkan kepada kepala sekolah TK IT An-Nur yang sudah memberikan saya kesempatan untuk bisa meneliti permasalahan penilaian kinerja guru pada sekolah tersebut.

\section{Daftar Rujukan}

[1] Y. Yuprastiwi et al., "Sistem Pendukung Keputusan Penilaian Kinerja Guru Menggunakan Metode Analytical Hierarchy Process ( AHP ),” pp. 266-272, 2020.

[2] Satria and A. S. Agustini, "Penerapan Metode Graphic Rating Scale ( Grs ) Dalam," J. Kilat, vol. 6, no. 2, pp. 139-148, 2017. 
